\title{
A Comprehensive Study of Talent Management Process adopted by Tata Consultancy Services (TCS)
}

\author{
Laveena C. Crasta ${ }^{1}$, \& Shailashri V. T. ${ }^{2}$ \\ ${ }^{1}$ Research Scholar, College of Management and Commerce, Srinivas University, Mangalore, \\ India \\ OrcidID: 0000-0003-0481-2156; E-mail: lavishalet@ gmail.com \\ ${ }^{2}$ Research Professor, College of Management and Commerce, Srinivas University, \\ Mangalore, India \\ OrcidID: 0000-0002-1684-238X ; E-mail: shailashrivt@gmail.com
}

Area of the Paper: Business Management.

Type of the Paper: Research Case Study.

Type of Review: Peer Reviewed as per $|\mathrm{C}| \mathrm{O}|\mathrm{P}| \mathrm{E} \mid$ guidance.

Indexed In: OpenAIRE.

DOI: http://doi.org/10.5281/Zenodo.5100377

Google Scholar Citation: IJCSBE

\section{How to Cite this Paper:}

Crasta, Laveena C, \& Shailashri, V. T., (2021). A Comprehensive Study of Talent Management Process adopted by Tata Consultancy Services (TCS). International Journal of Case Studies in Business, IT, and Education (IJCSBE), 5(1), 267-281. DOI: http://doi.org/10.5281/Zenodo.5100377.

International Journal of Case Studies in Business, IT and Education (IJCSBE) A Refereed International Journal of Srinivas University, India.

Crossref DOI : https://doi.org/10.47992/IJCSBE.2581.6942.0115

(C) With Authors.

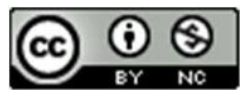

This work is licensed under a Creative Commons Attribution Non-Commercial 4.0 International License subject to proper citation to the publication source of the work.

Disclaimer: The scholarly papers as reviewed and published by the Srinivas Publications (S.P.), India are the views and opinions of their respective authors and are not the views or opinions of the S.P. The S.P. disclaims of any harm or loss caused due to the published content to any party. 


\title{
A Comprehensive Study of Talent Management Process adopted by Tata Consultancy Services (TCS)
}

\author{
Laveena C. Crasta ${ }^{1}$, \& Shailashri V. T. ${ }^{2}$ \\ ${ }^{1}$ Research Scholar, College of Management and Commerce, Srinivas University, Mangalore, \\ India \\ OrcidID: 0000-0003-0481-2156; E-mail: lavishalet@gmail.com \\ ${ }^{2}$ Research Professor, College of Management and Commerce, Srinivas University, \\ Mangalore, India \\ OrcidID: 0000-0002-1684-238X ; E-mail: shailashrivt@gmail.com
}

\begin{abstract}
Background /Purpose: Talent management is the kernel of human resource management, the process of procurement of the right people to be absorbed by a company based on its business requirements. The surge to absorb the right competency in the global market has forced every corporation to build a vibrant process to acquire the best, develop and engage the acquired effectively to achieve optimal results. This paper is a comprehensive study on acquiring information on the Talent Management process adopted by Tata Consultancy Services (TCS).

Design/Methodology/Approach: This study is based on the data collected from secondary sources of information. The main sources of information are annual reports of the company and websites. It is an explorative research case study that aims at identifying the best practices in terms of the Talent Management process and to perform SWOC analysis.

Findings/Result: Based on the study, TCS has a robust process in place not only to acquire the best talent but also to nurture the existing talent within the company. This well-established process has helped the company to have maximum employee retention, which is a great asset while considering the impact of human resourcefulness in the growth of the company.

Originality/Value: This paper analyses and interprets the Talent Management model of TCS based on its past 5 financial years of data. Based on the findings and their interpretation, new knowledge in the form of recommendations/suggestions are presented.
\end{abstract}

Paper Type: Company Analysis as a Research Case Study.

Keywords: Tata Consultancy Services, Company analysis, SWOC analysis, Talent acquisition, Talent management, Talent engagement.

\section{INTRODUCTION :}

Talent management is a vital process in every organization. It plays a quintessential role in the progress of the organization. The right person at the right job is an asset to the company which when nurtured can turn into a game-changer. Talent management has become a challenge not just to HR but to the company as a whole. Considering the competitive nature of the market that is growing at great speed, acquiring the right person at the right time for the right job is the need of the hour that cannot be neglected. Talent acquisition is a key area in talent management that has to do with acquiring highly talented and resourceful people. Having the right mindset and focusing on the key areas of business, will have a greater impact in adding value to the same. Talent management focuses on finding, attracting, hiring, growing, developing and retaining the top talent who are the greatest asset of the company. The company should hire both fresh and experienced candidates considering not just the current requirement but also having a futuristic perspective [1]. Companies today hire candidates who possess the skills of adaptability, problem-solving, creativity/ innovation and leadership to foster continuous growth. HR today has moved from the traditional method of hiring to digital hiring that provides equal opportunity to all probable candidates without any distinction. Businesses have moved into human resource information systems to help in the various functions of the HR domain [2]. Tata Consultancy Services (TCS) is one of the best Indian multinational companies known to attract the best talent. It is known as a good employer and has an established Talent Management process. 


\section{RELATED WORKS :}

Talent Management is a continuous process, an organisation should strive at. Many successful companies invest in Talent Management so that they can attract top talent, keep employees highly motivated, retain employees and outperform in business productivity. Several authors have contributed to this field of Talent Management.

Table 1: Review of Talent Management Process and Practices

\begin{tabular}{|c|c|c|c|}
\hline S. No & Area & Issue & Reference \\
\hline 1 & $\begin{array}{l}\text { Talent Acquisition } \\
\text { Practices at DXchange }\end{array}$ & $\begin{array}{l}\text { The complex and lengthy } \\
\text { process of talent acquisition }\end{array}$ & $\begin{array}{l}\text { Likhitha \& Pasha, (2019). } \\
\text { [1] }\end{array}$ \\
\hline 2 & Talent management & $\begin{array}{l}\text { Nurturing talent and retention } \\
\text { at TCS }\end{array}$ & $\begin{array}{l}\text { Rath, N., Rath, M. S., \& } \\
\text { GIFT, B, (2014). [2] }\end{array}$ \\
\hline 3 & Talent management & $\begin{array}{l}\text { Talent development \& talent } \\
\text { acquisition process at TCS }\end{array}$ & $\begin{array}{l}\text { (Kang, L. S., \& Sidhu, H. } \\
\text { (2011). [3] }\end{array}$ \\
\hline 4 & $\begin{array}{l}\text { Talent Acquisition in } \\
\text { Multinational company }\end{array}$ & $\begin{array}{l}\text { Talent acquisition, best } \\
\text { practices and areas of } \\
\text { improvement in ABSTOM } \\
\text { company. }\end{array}$ & $\begin{array}{l}\text { John Attupuram, } \\
\text { Sequeira, A. H., \& } \\
\text { Gopalakrishnan, } \\
\text { (2015). [4] }\end{array}$ \\
\hline 5 & $\begin{array}{l}\text { Talent Management } \\
\text { Strategy }\end{array}$ & $\begin{array}{l}\text { Analysis, Evolution \& } \\
\text { prominent features of talent } \\
\text { management. }\end{array}$ & (Rana, N, (2017). [5] \\
\hline 6 & Employee Retention & $\begin{array}{l}\text { Retention strategies adopted by } \\
\text { TCS and their impact on } \\
\text { attrition rate. }\end{array}$ & $\begin{array}{l}\text { (Kumar, M. M., \& Mohd., } \\
\text { D. K, (2017). [6] }\end{array}$ \\
\hline 7 & $\begin{array}{l}\text { Innovation a Key Towards } \\
\text { Employee Engagement. }\end{array}$ & $\begin{array}{lr}\text { Relationship between } & \text { Human } \\
\text { resource practices } & \text { and } \\
\text { Innovativeness } & \text { among } \\
\text { employees. } & \\
\end{array}$ & $\begin{array}{l}\text { Shailashri, V. T., } \quad \text { \& } \\
\text { Shenoy, S, (2016). [7] }\end{array}$ \\
\hline 8 & $\begin{array}{l}\text { Automated talent } \\
\text { acquisition system }\end{array}$ & $\begin{array}{l}\text { Process of transition and } \\
\text { challenges faced. }\end{array}$ & $\begin{array}{l}\text { Sengupta, D., Titus, R., \& } \\
\text { Sengupta, S, (2015). [8] }\end{array}$ \\
\hline 9 & $\begin{array}{l}\text { Recruitment and Selection } \\
\text { in MNC }\end{array}$ & $\begin{array}{l}\text { Recruitment and selection } \\
\text { process in TCS }\end{array}$ & $\begin{array}{l}\text { Gedela Rakesh Varma, P. } \\
\text { R. (2017). [9] }\end{array}$ \\
\hline 10 & Employee Engagement & $\begin{array}{ll}\text { Comprehensive } & \text { literature } \\
\text { review on } & \text { employee } \\
\text { engagement. } & \end{array}$ & $\begin{array}{l}\text { Nalini, G., \& Mohd, K. } \\
\text { (2019). [10] }\end{array}$ \\
\hline 11 & $\begin{array}{l}\text { Employee retention } \\
\text { strategies }\end{array}$ & $\begin{array}{l}\text { Impact of retention strategies in } \\
\text { employee turnover. }\end{array}$ & $\begin{array}{l}\text { James, L., \& Mathew, L, } \\
(2012) . \text { [11] }\end{array}$ \\
\hline 12 & Talent retention & $\begin{array}{l}\text { Study of Talent retention } \\
\text { strategies in the IT industry. }\end{array}$ & $\begin{array}{l}\text { Behera, R., \& Mohapatra, } \\
\text { A. D. (2020). [12] }\end{array}$ \\
\hline 13 & Employee engagement & $\begin{array}{l}\text { Role of Employee Engagement } \\
\text { in the growth of the company. }\end{array}$ & Garg, P. (2014). [13] \\
\hline 14 & $\begin{array}{l}\text { Recruitment, Selection } \\
\text { towards employee } \\
\text { engagement }\end{array}$ & $\begin{array}{l}\text { Role of recruitment and } \\
\text { selection towards effectively } \\
\text { engaging employees in an } \\
\text { organization. }\end{array}$ & $\begin{array}{l}\text { Shailashree, V., \& } \\
\text { Shenoy, S. (2016). [14] }\end{array}$ \\
\hline
\end{tabular}

Table 1 depicts the summary of the research papers in the fields of talent management, talent acquisition and automation, employee engagement and talent retention. Many authors have worked in the areas of talent management and have stressed the need for building a robust process to sustain business growth. It has been observed that talent acquisition and development go hand in hand in building a vibrant talent force for the future. 


\section{OBJECTIVES :}

This study has been taken up to gain insight into the Talent Management Process implemented or adopted by TCS. The primary objectives of this study are as follows:

(1) To understand the process of talent acquisition at TCS

(2) To explore the best practices adopted or implemented by the company towards talent development.

(3) To determine if talent management has an impact on attrition and women employment rate in the company.

(4) To perform SWOC analysis of the Tata Consultancy Services.

\section{METHODOLOGY :}

This case study has been carried out by making use of secondary sources such as Journals and Conference Proceedings, Annual Reports, Company Websites, articles published on the internet, reviews of employees given through social media and SWOC Analysis.

\section{OVERVIEW OF TCS :}

TCS is a global leader in IT services, consulting, and business solutions. For more than half a century it has been associated with the world's largest corporations to bring about transformation through business solutions. TCS provides an integrated range of business, technology and engineering services and solutions [24]. This is achieved through its unique Location TM Independent Agile delivery model, recognized as a benchmark of excellence in software development. TCS is a part of the Tata group and is India's largest multinational business group. It is ranked one among the best three most valuable global IT service brands. TCS is the preferred employer to a large sector of engineering students from all over India and abroad. The company uses various modes of bringing the best talent in through social networking sites, technology, gaming platforms to attract talent.

\section{THE PATH OF SUCCESS :}

Table 2: Path of success [15] [17]

\begin{tabular}{|c|l|}
\hline Year & \multicolumn{1}{|c|}{ Milestones } \\
\hline $\mathbf{1 9 6 8}$ & The inception of the company. \\
\hline $\mathbf{1 9 7 0}$ & Acquired ICL. \\
\hline $\mathbf{1 9 7 3}$ & Partnered with Burroughs. \\
\hline $\mathbf{1 9 7 6}$ & Crossed the \$1 million mark in export revenues. \\
\hline $\mathbf{1 9 7 9}$ & First sales office in New York. \\
\hline $\mathbf{1 9 8 1}$ & Opened its research wing TRDDC. \\
\hline $\mathbf{1 9 8 2}$ & $\begin{array}{l}\text { Built the Advanced Data Dictionary (ADDICT), a global repository of project } \\
\text { information. }\end{array}$ \\
\hline $\mathbf{1 9 8 4}$ & Launched the Falcon (Fast Access Local Computer Network). \\
\hline $\mathbf{1 9 8 7}$ & Set up the IBM mainframe Centre of Excellence in Madras. \\
\hline $\mathbf{1 9 8 8}$ & Launched the Integrated Standard Banking System which \\
\hline $\mathbf{1 9 9 1}$ & Launched a user-friendly accounting software package called E.X. in India. \\
\hline $\mathbf{1 9 9 2}$ & $\begin{array}{l}\text { Set up the core trading platform for the newly created National Stock Exchange, which } \\
\text { changed the way capital markets worked in India. }\end{array}$ \\
\hline $\mathbf{1 9 9 5}$ & $\begin{array}{l}\text { Launched the Network Custody System (NCS), a new product to meet regional clearing } \\
\text { and custody functions, in partnership with Standard Chartered Bank in Singapore. }\end{array}$ \\
\hline $\mathbf{2 0 0 0}$ & Unveiled a new \$2 Million global e-business development facility in Mumbai. \\
\hline $\mathbf{2 0 0 1}$ & Won the largest banking software project in India \\
\hline $\mathbf{2 0 0 3}$ & Crossed the \$1 Billion mark in annual revenue \\
\hline
\end{tabular}




\begin{tabular}{|l|l|}
\hline $\mathbf{2 0 0 5}$ & Launched the 'Experience Certainty' tagline. \\
\hline $\mathbf{2 0 0 8}$ & Acquired Citigroup Global Services Ltd \\
\hline $\mathbf{2 0 1 1}$ & $\begin{array}{l}\text { Launched iON, a fully integrated cloud-based, pay-per-use platform for Small and } \\
\text { Medium Businesses in India. }\end{array}$ \\
\hline $\mathbf{2 0 1 3}$ & Acquired French IT services firm ALTI SA \\
\hline $\mathbf{2 0 1 4}$ & $\begin{array}{l}\text { Launched a cognitive automation product, ignio } \\
\text { IT arm in Japan. }\end{array}$ \\
\hline $\mathbf{2 0 1 6}$ & $\begin{array}{l}\text { Opened Executive Briefing Center in Mumbai, India, and the Digital Reimagination } \\
\text { Studio in Santa Clara, CA. }\end{array}$ \\
\hline $\mathbf{2 0 1 7}$ & Unveiled the Business 4.0 thought leadership framework. \\
\hline $\mathbf{2 0 1 8}$ & Signed three large, industry-defining digital transformation deals. \\
\hline
\end{tabular}

\section{TALENT ACQUISITION PROCESS :}

The talent acquisition process can be carried out by considering various aspects, some of which could be the following.

1. Developing employees

2. Screening people for their abilities

3. Screening More Rigorously

4. Bringing Brand Management to Campus

5. Using Digital Hiring and Screening technology

6. Marketing the Brand Broadly as a Great Place Work

Recruiting the talent, selecting the talent, training and development, retention, promotion, competency mapping, performance appraisal, career planning are the important aspects of talent acquisition [5]. Every organization has its process towards acquiring the right talent, the researcher discusses here the process adopted by TCS. TCS has a valuable acquisition strategy to hire candidates with the right competencies required by the business at the right time, which has to do with a blend of lateral hires and trainees. TCS has also been a key player to promote research through its research scholarship programme. Fig 1 shows the comprehensive process of talent acquisition at TCS which has the academic interface, national qualifier test, campus commune and gamified hiring. All the components play a vital role in acquiring the best talent by giving equal opportunity to all the candidates seeking to be associated with TCS.
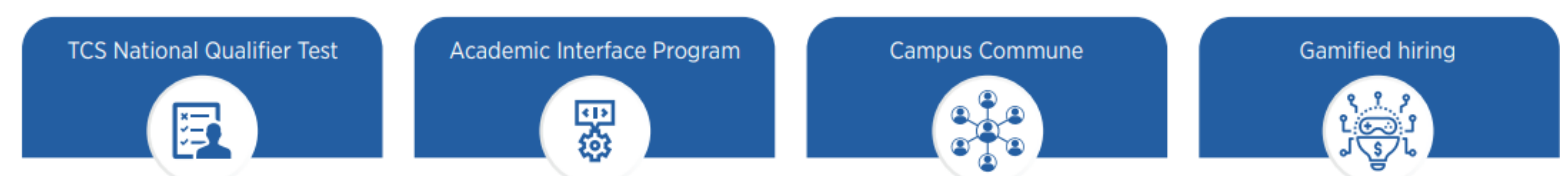

Fig. 1: Overview of different approaches to the talent acquisition process Source: Annual reports of TCS [16]

7.1 TCS National qualifier test: This is a nationwide online test conducted via TCS' digital platform, TCS iONTM. With the exponential demand for expertise in technology, TCS has deployed this method to identify and retrain candidates who are a good fit for the company [18]. This process helps prospective candidates from nationwide to the talent ecosystem by going beyond the college campus. Successful completion of the test would lead to a TCS incorporated video interview which has proved to be very cost-effective to the company. This platform has bought in the participation of over 3,36,000 students from 2500 colleges. This programme was launched in 2019.

7.2 Academic Interface program: According to TCS, academic institutes are the main stakeholders in the overall process of acquiring talent. They are crucial to build the quality talent pool through continuous interaction with various educational institutions [25]. TCS has partnered with several academic institutions to boost the quality of its curriculum and pedagogy. TCS conducts various programmes that enhance the skills of the student community to upgrade their knowledge and skills 
that help in being industry-ready. The recent annual report of the company highlights its academic interface with institutes to have not just the students, but the faculty also developed to have the best result in terms of talent pursuit. Table 3 and fig 2 shown below gives a descriptive and pictorial representation of the number of institutes that have been a part of the TCS- Academic interface. Many institutes have been a part of the TCS academic interface programme as it brings along with it rich expertise of company or industry perspective.

Table 3: Count of institutes in the Academic Interface program

\begin{tabular}{|l|l|l|l|l|l|}
\hline & FY2016 & FY 2017 & FY2018 & FY 2019 & FY 2020 \\
\hline Number of institutes & 900 & 1232 & 706 & 806 & 711 \\
\hline
\end{tabular}

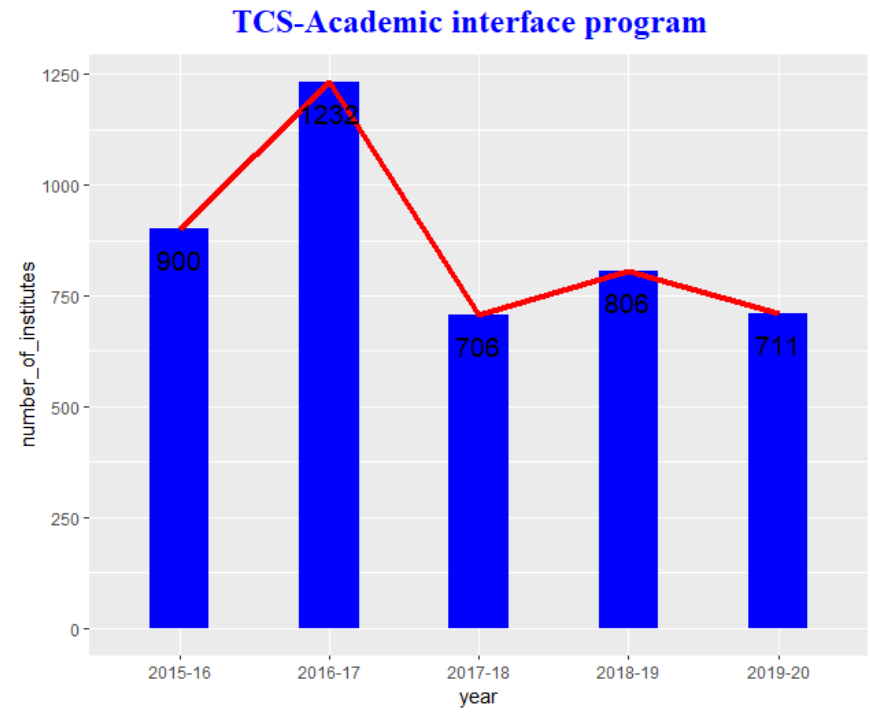

\subsection{Campus commune:}

Fig. 2: Year-wise data on the number of institutes associated with TCS

TCS has a "Campus commune" portal that helps the students to prepare to join the company. It's a unique student engagement portal for collaboration and peer networking, featuring webinars, educational videos, and expert blogs. An approximate of nearly 2.3 million students are a part of this portal, which creates quite an impact on building talent. CodeVita is a global programming competition that attracts thousands of students all over the globe. Among the several other contests, TESTimony, EngiNx, GameOn, are used to spot and hire top talent [19]. Table 4 and Fig 3 show the tabular and diagrammatic view of the students who have been a part of the campus commune over the years. The growth in terms of the number of students being a part of this talent hunt has been enormous. It shows that there has been a steady increase in the number of students who have been a part of the campus commune program of TCS. It also indicates the amount of influence that it has on the student community.

Table 4: Count of Students in campus commune

\begin{tabular}{|l|l|l|l|l|l|}
\hline & FY2016 & FY 2017 & FY2018 & FY 2019 & FY 2020 \\
\hline Number of students & $\mathbf{8 9 1 4 2 9}$ & $\mathbf{1 0 , 0 0 , 0 0 0}$ & $\mathbf{1 5 , 0 0 , 0 0 0}$ & $\mathbf{1 2 , 0 0 , 0 0 0}$ & $\mathbf{2 3 , 0 0 , 0 0 0}$ \\
\hline \multicolumn{6}{|c|}{ Source: Annual reports of TCS $[25]$}
\end{tabular}




\section{TCS-Campus Commune}

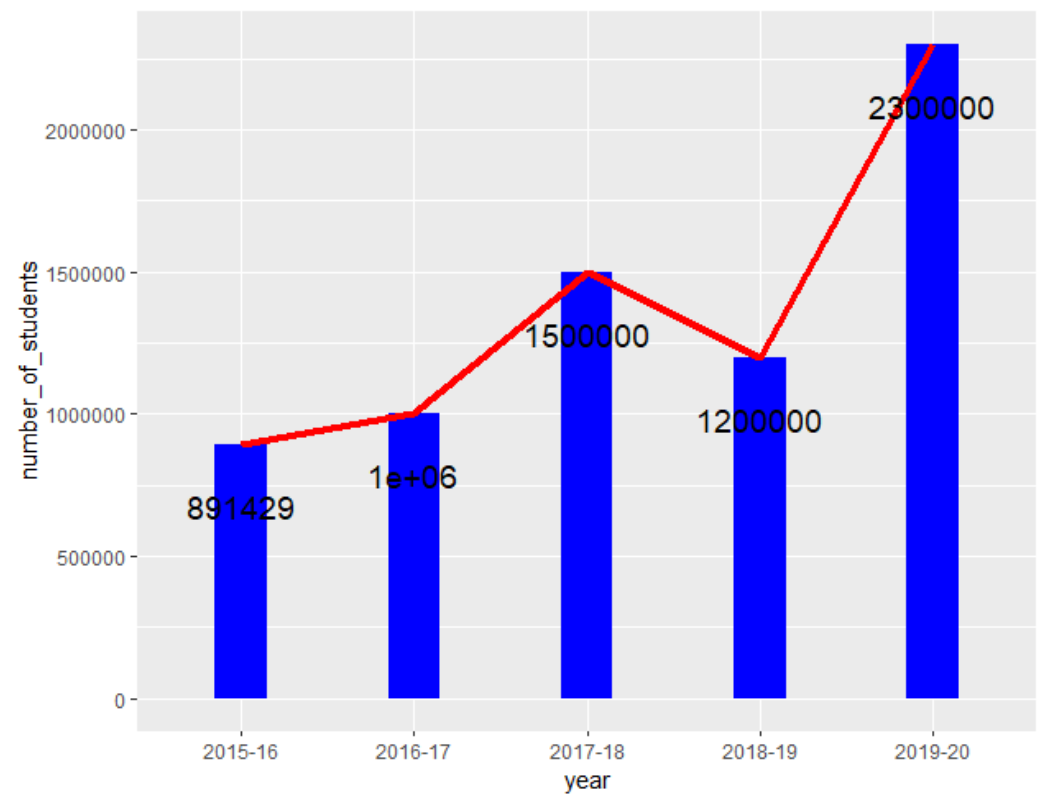

Fig. 3: Year-wise students associated with TCS

7.4 Gamified hiring: TCS has gamified its hiring through contests on its student portal - Campus Commune. The portal has contests like CodeVita (on global programming), EngiNX (on engineering, design and innovation, themed around IoT), HackQuest (on ethical hacking), EnQuode (on quality engineering), and InfraMind (on IT infrastructure with a focus on cloud computing and automation). The contests allow students to not only explore their skills in specific areas of technology but also to identify the various other skill sets that need to be acquired. This has led to sharpening talent search and creating an effective employee value proposition among employees and potential recruits. Table 5 shows that spotting top talent through gamification has increased the hiring count. Over the years the number of students participating in gamification has increased indicating a positive impact of gamification. This approach is a very well-accepted one among students as it triggers the creativeness in them to bring out the best possible talent. Over the years, this could be a major hiring technique that can boost in finding competitive recruits given a specific scenario.

Table 5: Hiring count through Gamification

\begin{tabular}{|l|l|l|l|l|l|}
\hline & FY 2016 & FY 2017 & FY 2018 & FY 2019 & FY 2020 \\
\hline Participation & 197639 & 260000 & & $2,00,000$ & $2,30,000$ \\
\hline Hiring count & & & 1100 & $>2000$ & $>3000$ \\
\hline
\end{tabular}

Source: Annual reports of TCS

\section{BEST PRACTICES ADOPTED TOWARDS TALENT MANAGEMENT BY TCS :}

TCS has assimilated a very good approach towards talent management within the company to build a strong talent-driven workforce that is always prepared to take up the challenges emerging at various time points. Some of the practices are as follows:

- Talent Development

- Career Management

- Talent Diversity

- Talent Engagement

\subsection{Talent Development:}

Developing employee competency and improving organisational competency is the main focus of talent development. TCS has advanced into setting up platforms through various programmes to re-skill and equip its employees with various skills that will help them to stay up to date in the digital era. They have emphasised experiential learning by providing the necessary infrastructure which is available "any place, any time and on any device". The learning methods are also assisted by mentors who provide 
constant coaching and help with proper career advancement. This has turned the employees to build a constant learning process that will prepare them to face the challenges of the digital world. The company has moved towards an employee-centric 'pull' model from the 'push' model of training keeping in mind the continuous changes taking place in digital technology. This has created a positive impact on the employees with better skill sets.

Talent development at TCS has various tracks such as [28] -

- Initial Learning Programme (ILP)

- Continuous Learning Programme (CLP)

- Leadership Development Programme (LDP)

- Cultural and language Initiatives (CLI)

ILP was developed to have a smooth transition from the campus to the corporate world by transforming graduates into IT consultants with a global mindset [28]. The company uses a blend of a learning platform (iON), digital interactive classrooms (iQlass), virtual labs and a competency tracking platform (iEvolve) to facilitate learning opportunities for employees worldwide. The state-of-the-art infrastructure enables learning to be carried out very smoothly. A continuous learning programme (CLP) is a platform that empowers employees to be on par with the technological developments and strategies adopted by its clients to understand the business prospect in a better way. This highly depends on the clients and their business strategies, project needs, technology and business direction along with individual aspirations [29]. 'Aspire', is the company's digital ILP that surpasses the topographical boundaries and facilitates the new talent to be a valuable asset of the company at a faster rate.

The much-needed talent is to build the next level leaders who will strive in keeping up to the pace at which the company is growing by equipping themselves with the recent advancements. LDP plays a vital role in this direction and has tailored programmes at each level and career path. The training process is customized based on the reviews and redesigned taking into consideration the changing nature of business and the global diverse workforce. TCS has collaborations with globally recognised coaching agencies to provide coaching intervention to its leaders [2]. The company has also launched programmes to develop women employees for leadership roles as a part of women empowerment. The company has several initiatives towards developing talent by helping employees to climb the ladder of success.

CLI main focuses on three C's - Culture, Communication and Collaboration. The main initiatives through this platform are country-specific 'culture shots' by offering guidance for the first-time visitor to a new country, training in English for non-English speaking employees and training in 11 foreign languages. As per the recent annual report, the talent development can be summarised as follows:

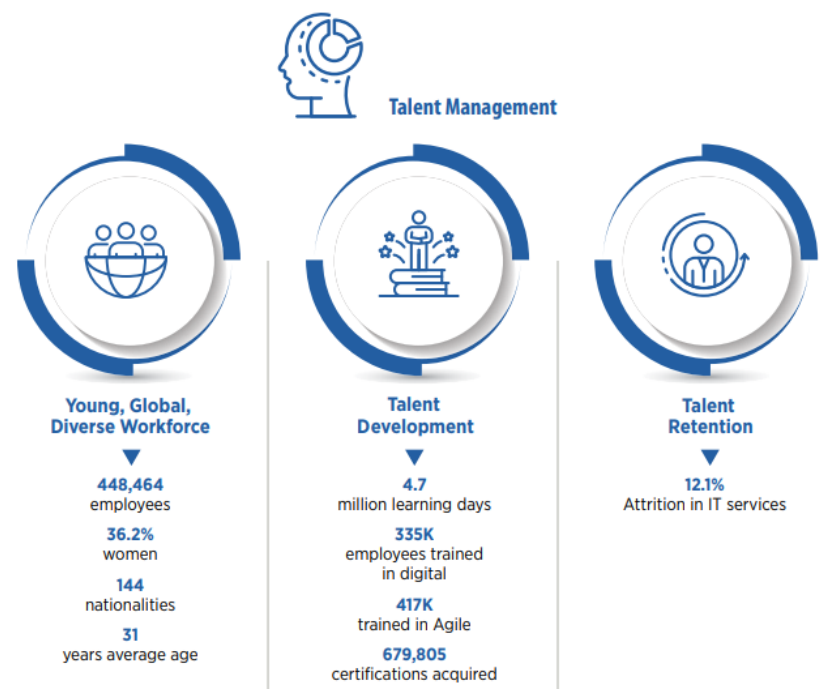

Fig.4: Talent Management at TCS

Source: TCS Annual Report [18]

\subsection{Career Management:}

TCS has multiple initiatives to promote career growth amongst its employees. Some of them are discussed here. 'CareerHub': It is a platform that provides mentoring services to employees. It captures 
employees' career aspirations and provides mentoring services. This helps employees to choose their mentor, based on a match, with their aspirational skill sets. 'Inspire', a specialized program that provides fast-track career progression to high-potential employees. TCS has many structured programs at senior leadership levels so that the employees realize their full potential. There is a system of review of leadership and assessment profile of all leaders to have a healthy succession pipeline.

\subsection{Talent Diversity:}

TCS believes in including people of various backgrounds in the company without creating distinctions based on gender, disability, culture to provide equal opportunity to job seekers to work at TCS. It also creates an environment of inclusiveness by enhancing workplace diversity. Through 'Talent Diversity', the company aims to invest and optimize its global presence to pursue opportunities in the global market as an ongoing process [3]. 'Diversity' and 'Inclusion' are the two sides of a coin that are highly interdependent in understanding the unique skills and perspectives of an individual that enable in creating an environment that encourages and respects these to build a better organisation. An effective diversified approach amalgamates this viewpoint into all the processes of the organisation to have a better work environment [21]. TCS has been an Equal Opportunity Employer by understanding that diversity which is in many forms such as gender, caste, religion, culture, age, academic discipline, etc. benefits the organisation. It has a well-defined Diversity and Inclusion policy. TCS is one of the world's largest employers of women, it has to its credit an all women centre for business processes and IT services in Riyadh, Saudi Arabia with 1000 women employees of which 85\% are local hires. This milestone is a major step in the process of empowering women. The organization is sensitive towards parenthood and has policies such as extended leave, special focus on the security of women employees, re-orientation programmes after long leave, focused mentoring, special leadership programmes to help its women employees to meet their aspirations. Compensation levels are purely based on merit and do not have gender or any other diversity parameters associated with it. TCS' diversity-focused talent acquisition strategy has a wide diversity of talent in the company which has enhanced its employee performance to a large extent. TCS not only has a diversified workforce but also promotes this diversity with the client organisations who are associated with it. It has various initiatives like Be-Inspired, nWin, Workplace Parents Group, etc to help its employee attain their maximum potential through proper intervention and create a work-life balance.

\subsection{Talent Engagement:}

Cara: This is an HR bot that was introduced by TCS to answer the routine queries instantly, which was not possible manually. "Cara can answer HR policy and process queries anytime, anywhere, thereby saving valuable productive time and effort of our people"[22].

Milo: A chatbot that helps with the mentoring process.

Knome, KnowMax, GEMS: These platforms help the employees for better social collaboration within the organisation, to learn, share and to be a part of the reward and recognition [22].

Safety First: This is an initiative that emphasises employee safety and security [18].

Fit4life: This helps in ensuring fitness culture among the workforce to build their health and fitness. This Corporate Challenge intends to promote fitness amongst employees and also creates social awareness [23].

'Purpose4life' creates corporate social responsibility by helping society at large through some projects as an act of giving back to society, which in turn increases employee bonding. This also helps in promoting the work-life balance of the company, which in turn helps in employee retention [24].

Maitree: A community of TCS employees and their families which helps in improving employee bonding and builds a better work-life balance through various activities. Through this initiative, TCS aims at cultivating and propagating volunteer-driven, meaningful activities for its employees and their families [6].

PULSE TCS annual employee engagement and satisfaction Survey, which is the formal listening forum of the organization. This is a measure that helps the employees to have a sense of ownership towards the Company and their support to "One TCS" belief. This helps in getting to know the employees, their work satisfaction or any other grievances which in turn will help in studying the tendency of turn-over as well [25].

TCS Cares aims to build a workforce that is emotionally strong and mentally resilient [26]. 
Through talent management and talent engagement process, the organization has created a performance-driven environment where innovation is appreciated, performance is acknowledged and employees are motivated to optimize their potential. With all the initiatives taken by the company towards talent acquisition, development and retention, the following table show the impact on the employees. The attrition rates are smaller compared to that of the retention rate. The company is progressing at great speed concerning the number of personnel being attracted and hired by the company. This indicates that the acquisition process of the company is up to date and is undergoing continuous change as per the market demand.

Table 6: Total Headcount over the years at TCS

\begin{tabular}{|l|l|l|l|l|l|}
\hline Year & $\mathbf{2 0 1 5 - 1 6}$ & $\mathbf{2 0 1 6 - 1 7}$ & $\mathbf{2 0 1 7 - 1 8}$ & $\mathbf{2 0 1 8 - 1 9}$ & $\mathbf{2 0 1 9 - 2 0}$ \\
\hline Total Headcount & $\mathbf{3 5 3 8 4 3}$ & $\mathbf{3 8 7 2 2 3}$ & $\mathbf{3 9 4 9 9 8}$ & $\mathbf{4 2 4 2 8 5}$ & $\mathbf{4 4 8 4 6 4}$ \\
\hline \multicolumn{6}{|c|}{ TCS- Total Head Count }
\end{tabular}

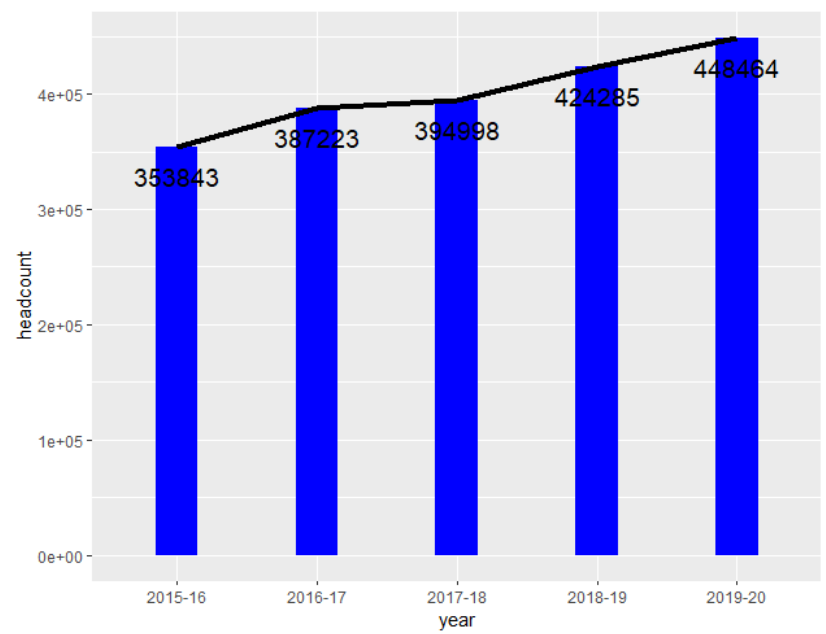

Fig. 5: Year wise data on total headcount at TCS

Fig 5 and Table 6 gives a clear impact of the talent acquisition process taking place in the company in terms of employee strength that is growing linearly over the years. TCS has been the major recruiter in the country for years and the most sought-after firm by the student community for its well-established approach to talent management.

Table 7: Attrition rates in \% at TCS

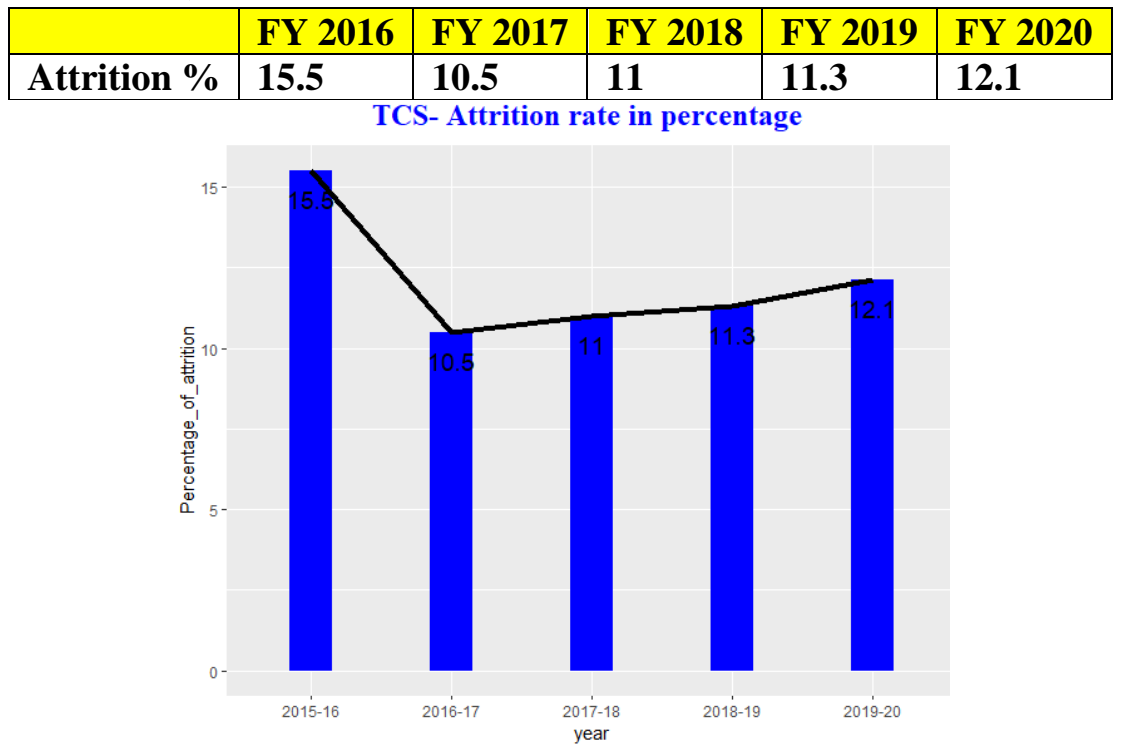

Fig. 6: Year-wise data on attrition rate at TCS

Table 7 and Fig 6 shows the percentage attrition rate of the company for 5 years, which though shows an upward trend, is under control. The company is working towards decreasing its attenuation rate through various measures through a proper talent engagement process. It has various programmes like 
Cara, Milo, Safety first, Fit4life, TCS cares, Awards and Recognitions to have a better bonding with the employees, which in turn will improve their retention rates.

Table 8: Women employee rates in \% at TCS

\begin{tabular}{|l|l|l|l|l|l|}
\hline Year & $\mathbf{2 0 1 5 - 1 6}$ & $\mathbf{2 0 1 6 - 1 7}$ & $\mathbf{2 0 1 7 - 1 8}$ & $\mathbf{2 0 1 8 - 1 9}$ & $\mathbf{2 0 1 9 - 2 0}$ \\
\hline Women \% & $\mathbf{3 3 . 8}$ & $\mathbf{3 4 . 7}$ & $\mathbf{3 5 . 3}$ & $\mathbf{3 5 . 9}$ & $\mathbf{3 6 . 2}$ \\
\hline
\end{tabular}

TCS- Women Employee percentage

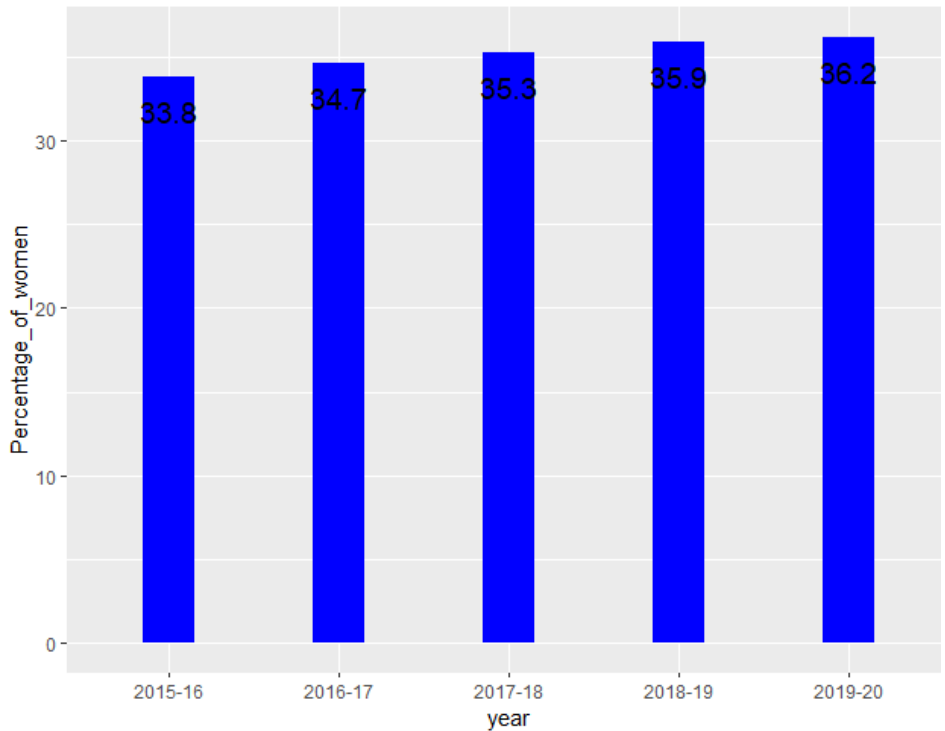

Fig. 7: Year-wise data on \% of women employees at TCS

Table 8 and Fig. 7 gives an overview of the percentage of women in the company. There is a uniform growth of women employees in the company. The company has various programmes initiated to improve women empowerment and safety measures. The company provides special and extended leave towards motherhood and then helps them reconnect through re-orientation. TCS employs more women compared to its competitors.

\section{SWOC ANALYSIS OF TCS :}

SWOC is used to analyse a company's performance according to its strengths, weaknesses, opportunities, and challenges. It opens up a platform where you can dig deeper into your company's stronghold, identify weaknesses to overcome them, know its future opportunities to make the best of them, and face challenges to succeed. This is an effective tool for a better understanding of the business and enables the corporations to prioritize in the right direction [31].

Table 9: SWOC Analysis of TCS

\begin{tabular}{|c|c|}
\hline Strengths & Weakness \\
\hline $\begin{array}{ll}\text { - } & \text { Job security } \\
\text { - } & \text { Employee strength with diversity } \\
\text { - } & \text { Healthy work environment } \\
\text { - } & \text { Health benefits } \\
\text { - } & \text { Elaborate training } \\
\text { - } & \text { Next-gen learning and development } \\
\text { - Industry academia collaboration } \\
\text { - Influence on higher education }\end{array}$ & $\begin{array}{l}\text { - } \text { Compensation is not competitive } \\
\text { - } \text { Promotions/ growth is very slow } \\
\text { - Salary is lesser } \\
\text { - Business Travel } \\
\text { - } \text { The recruitment process is slow } \\
\text { - Approvals take a long time } \\
\text { - Beauracratic in nature }\end{array}$ \\
\hline Opportunities & Challenges \\
\hline $\begin{array}{l}\text { - Increased digital trend } \\
\text { - } \\
\text { More bots can be deployed for } \\
\text { - Intensies } \\
\text { hiring }\end{array}$ & $\begin{array}{l}\text { Large organization with multiple } \\
\text { levels of authority } \\
\text { - The long decision-making process } \\
\text { and people dependent } \\
\text { - Grooming non-technical candidates }\end{array}$ \\
\hline
\end{tabular}




\begin{tabular}{|l|l|}
\hline & - New selects get lost in this big ocean \\
& - Global competition / Intense \\
& competition \\
- Immigration restrictions & - Attrition rate \\
\hline
\end{tabular}

\subsection{Strengths:}

TCS, one of the leading IT services of the world, has a brand image that is very strong in the IT sector. Its unique strength lies in its employee strength of over 400000. The company encourages and builds on the aspect of talent diversity that has helped it to grow in providing a healthy work environment to its employees. It has a well-defined Diversity and Inclusion policy. The company offers intensive and elaborate training to its employees at various stages viz., absorbing, parental leave which helps the employees to connect/reconnect to the working environment. A tremendous amount of constant learning and development taking place through various platforms that help to keep the employees up to date with the current development in the IT service sector. It provides the importance of employee safety and health benefits to its employees and has created a great impact of belongingness among them. The company has a strong industry-academic relationship with the top institutes within India and worldwide which plays a vital role in acquiring the right talent. The various programmes hosted by TCS through the academic interface have influenced higher education to a large extent. It has also helped in bridging the gap between industry and academia by giving the necessary training to the faculties to deliver on par with industry requirements.

\subsection{Weakness:}

Although the company follows a very systematic process towards compensation, it's not on par with its competitors. The process of promotion is very slow leading to attrition among employees. Considering the magnitude of the company across the world and with over 400,000 employees, it follows a very lengthy process towards approval of any kind. This in turn delays certain processes which need immediate action. The redundant queries that need to be addressed move through a lot of human interventions that could lead to delay in getting the necessary answers, which in turn slows down the process. There is a lot of travel involved among employees due to the magnitude and spread of the company, which could be a difficult phase for the family members of the employees to cope with. The recruitment process is slow, and it takes a lot of time to induce new recruits into the company when compared to other competitors. This in turn leads to a sense of fear amongst the new recruits, which could lead to loss of good talent.

\section{Opportunities:}

As the world today is moving at an exponential speed towards digitization, the demand for IT services is soaring very high. This will help the company to grow and expand into new horizons. The pandemic that we are facing today has forced almost every sector to move online and digitize every field. This has also created an opportunity towards identifying talent from all over the world through the digital process of hiring to acquire the best in the market. The company has already moved towards digital hiring through NQT (National qualifier test) and the current opportunity will add more advantages in this direction. The company has an added advantage to explore more of its digital technologies in enhancing the scale, quality and experience of talent acquisition, talent development and talent engagement [27].

\subsection{Challenges:}

The magnitude of the company, which on one hand is its strength, is also a concern when it comes to decision making as it is time-consuming due to the multiple levels of hierarchy that exist in the company. The new recruits take a lot of time to adjust and gain acquaintance within the company. The competition in the global market is a massive challenge towards acquiring the right talent and delivering the best to the clients. Another major challenge is the immigration restrictions that are enforced by various countries that need to be considered when the employees take business travel or relocate to another country. Though the attrition rate of the company, when compared to its competitors, is quite 
small, yet the company needs to strategize on retaining its talent as the IT field flourishes and the demand to absorb the right talent is at its peak.

\section{RECOMMENDATIONS :}

Based on the study done through various secondary sources, the company is performing extremely well in almost all aspects. The time consumed in addressing the redundant queries can be assisted by a chatBot instead of human intervention. The company can move towards familiarizing itself with new recruits through some innovative activities which could boost the employees to have better acquaintance and perform accordingly. Short-term business travel could be considered instead of long-term ones. It would be better to assign employees who are willing to relocate to assignments abroad. The company can also think of training its personnel in its branch countries so that they are well prepared for any challenges ahead.

\section{CONCLUSION :}

A comprehensive study of the Talent Management Process of TCS was undertaken in this paper. Based on the analysis of the company, this study has gained insights into the talent acquisition process at TCS. The company plans to hire the best talent to improve its competitiveness in the global market. It follows a robust process for the same by being well-connected with the premier educational institutes in India and abroad to have the upper hand to choose the creamy layer of talent. The academic interface can be made more viable if both the industry and academia understand the needs and constraints of each other and work towards it. The company has the best practices of acquiring talent through the academic interface, Campus commune, Gamified hiring, and its recent addition of the National qualifier test. These have enhanced the talent acquisition process of the company. According to this study, the company invests a large amount of time and resources into talent management by developing talent within the company. TCS believes in constant learning and providing a platform to learn for all its employees. This is an impressive move towards keeping the employees on par with the continuous development taking place in the IT sector. The company has a remarkable talent management process that helps in developing the acquired talent, engaging them fruitfully towards delivering their best by providing optimal results that help to achieve the business objectives. Overall, the company has an unparalleled retention rate due to some of its best practices like talent diversity, career management, and the process of promotion which is unbiased. Based on the SWOC analysis, the company is performing exceptionally well in terms of talent engagement and talent development. A healthy work environment and health benefits are an added advantage towards the same. Considering the enormous growth in the digital sector, TCS will emerge as a great giant in the IT field by expanding into new horizons.

\section{REFERENCES :}

[1] Likhitha, K., \& Pasha, D. M., (2019). A Study on Talent Acquisition Practices at DXchange. International Journal for Research in Applied Science \& Engineering Technology, 7(IX), 510514.

[2] Rath, N., Rath, M. S., \& GIFT, B., (2014). Talent Management in TCS. Business and Enterprises Applications. International Journal of Engineering, Business and Enterprise, 1(8), 90-93.

[3] Kang, L. S., \& Sidhu, H., (2011). Talent Management at Tata consultancy services. Global Business Review, 12(3), 459-471.

[4] John Attupuram, P., Sequeira, A. H., \& Gopalakrishnan, S., (2015). Talent Acquisition Process in a Multinational Company: A Case Study. (December 24, 2015, http://dx.doi.org/10.2139/ssrn.2708086.

[5] Rana, N., (2017). A Study of Talent management strategy at select IT Companies. International Journal of Business Administration and Management, 7(1), 118-130. 
[6] Kumar, M. M., \& Mohd., D. K., (2017). Employee retention strategy - a study in TCS company. International Research Journal of Management Sociology \& Humanity (IRJMSH), 8(6), 250258.

[7] Shailashri, V. T., \& Shenoy, S., (2016). Innovation a Key Towards Employee Engagement. International Journal of Management, Technology and Social Sciences (IJMTS), 1(1), 43-47.

[8] Sengupta, D., Titus, R., \& Sengupta, S., (2015). Transition to an automated online talent acquisition system in an IT project-based organization: A case study. PM World Journal, 4(7), $1-16$

[9] Gedela Rakesh Varma, P. R., (2017). Recruitment and Selection in MNC: A Case Study on TCS (Tata Consultancy Service). International Journal of Research in Management Studies, 2(5), 612 .

[10] Nalini, G., \& Mohd, K., (2019). Employee Engagement: A Literature Review. IJRARInternational Journal of Research and Analytical Reviews (IJRAR), 6(1), 524-527.

[11] James, L., \& Mathew, L., (2012). Employee retention strategies: IT industry. SCMS Journal of Indian Management, 9(3), 79 - 87.

[12] Behera, R., \& Mohapatra, A. D., (2020). Talent retention strategy in the Indian IT industry: a review-based study. Journal of Critical Reviews, 7(14), 1568-1577.

[13] Garg, P., (2014). Impact of employee engagement on IT sector. International Journal of Management Research and Reviews, 4(1), 62-72.

[14] Shailashree, V., \& Shenoy, S., (2016). Study to identify the relationship between recruitment, selection towards employee engagement. International Journal of Scientific Research and Modern Education (IJSRME), 1(2), 149-155.

[15] Nadkarni, D., (2012). The TCS Story... and Beyond. Anvesha, 5(3), 51-52.

[16] Tata Consultancy Sevices. https://www.tata.com/business/tcs Accessed on June 19, 2021.

[17] TCS-50. https://www.tcs.com/tcs-50 Accessed on April 18, 2021.

[18] TCS. (2019-20). Annual Report Purpose Driven Resilient Adapatable.

[19] Nurturing human capital., from https://www.tcs.com/: https://www.tcs.com/nurturing-humancapital Accessed on April 25, 2021.

[20] Business Artificial intelligence. https://www.tata.com/newsroom/business/artificial-intelligencetata-group-companies Accessed on April 29, 2021.

[21] Tata Drives Employee Adoption of Social Platform. https://www.tcs.com/tata-drives-employeeadoption-of-social-platform Accessed on April 29, 2021.

[22] TCS Fit\$life Corporate Challenge to Promote Wellness in the Community. https://www.tcs.com/tcs-fit4life-corporate-challenge-promote-wellness-community Accessed on April 29, 2021.

[23] Volunteering. https://www.tcs.com/volunteering Accessed on April 25, 2021.

[24] Business and Technology Insights. from https://www.tcs.com/blogs/improving-employeeexperience-leveraging-feedback-analysis Accessed on April 29, 2021.

[25] TCS. (2015-16). Annual Report Shaping The Future. Pune.

[26] TCS. (2016-17). Annual Report Reimagining the Enterprise. 
International Journal of Case Studies in Business, IT, and Education (IJCSBE), ISSN: 2581-6942, Vol. 5, No. 1, June 2021

[27] The Ascent of Smarter, Faster, Lighter Enterprises. https://www.tcs.com/perspectives/articles/winning-todays-talent-race Accessed on April 19, 2021.

[28] TCS. (2017-18). Annual Report Dawn Of Business 4.0.

[29] TCS. (2018-19). Annual Report Growth and Transformation with Business 4.0.

[30] Business Diversity Matters. https://www.tata.com/newsroom/diversity-is-good-for-business-tcs Accessed on May 4, 2021.

[31] Aithal, P. S., \& Kumar, P. M., (2015). Applying SWOC analysis to an institution of higher education. International Journal of Management, IT and Engineering, 5(7), 231-247. 